\title{
Investigating Metacognitive Listening Strategy and Listening Problems Encountered by English Learners
}

\author{
Sarita Merilia \\ Universitas Pamulang \\ dosen01710@unpam.ac.id
}

\begin{abstract}
Among listening strategies that are proposed by experts, metacognitive is one of important strategies in language learning. Metacognitive strategies help students understand the way they learn and the steps they take. Hence, learners will success in learning a language. The study investigated metacognitive listening strategies awareness and the listening difficulties among the second semester students at Faculty of Letter of Universitas Pamulang academic year 2017/2018. Out of 300 students of the population, 131 students ( 99 females and 32 males) were chosen as the samples based on the random sampling. The data in this study were obtained through questionnaires (MALQ, Vandergrift et al, 2006) and open-ended questionnaire. This study revealed that overall the highest level of the students' metacognitive awareness is problem solving and the lowest is directed attention. The students identified a number of factors that contribute to difficulties in listening comprehension: lack of vocabulary, speaker speed, accent, pronunciation, concentration, and other problems. In this paper, the findings and conclusion are discussed for classroom instruction and note substantive concerns that should be addressed in future research.
\end{abstract}

Keywords: English learners, listening problem, listening skill, metacognitive, strategy

\section{INTRODUCTION}

One of the reasons to learn language is to be able to communicate using the language. With language, we can express our thought or idea, travel around the world, do business, etc (De Valoes, 2014; Ahmed, 2016). Listening is one of important skills in communication. Holden (2004) conveys that adults spend 40$50 \%$ of their communication time engaged in listening, and 50\% others for writing, speaking and reading. That shows how listening gives great contribution on communication. To communicate well and effectively, people should have good listening ability. Ahmed (2016) states that communication is a skill which involves systematic and continuous process of speaking, listening and understanding. Hence, it is important to mastering listening skill as students. It is also important for teacher to know appropriate strategy in learning teaching listening process.

In English learning and teaching, listening is a skill that is learnt by learners equally with another skill. Since one of the purposes of language is to communicate, listening takes an important role in the language. It means listening is one of the English skills which must be mastered by English learners. On other hand, mastering listening skill is not easy for some students. Most students have difficulties in learning listening skill. Moreover, it is their first experience in learning listening.

Students who experience their first listening challenge some problems. The problems are varied. They do not familiar with various listening accents. In the first to second semester, it is the adaptation process for students with new listening accents. In listening classes taught, the students challenge listening speed, vocabularies and language function used by the speaker. 
Additionally, some other external problems also affect students listening ability.

To overcome the problems they are facing, it is hoped that they have their own strategy in listening. Having learning strategy can help students to improve their listening comprehension ability (Liu, 2008). With certain listening strategy, students will plan and organize the learning process so that students will recognize the problems easily and able to find the solution quickly. Vandergrift, (1997) define listening comprehension strategies as steps taken by learners to help them acquire, store, retrieve, and/or use information.

There are some strategies in learning listening. One of them is metacognitive learning strategy. Oxford (1990) classifies the strategy into six strategies; memory strategy, cognitive strategy, compensation strategy, metacognitive strategy, affective strategy and social strategy. Some studies have proved the role of metacognitive awareness in students' learning outcome and achievement. Metacognitive has important role than other strategies. Once a learner understands how to regulate his/her own learning through the use of strategies, language acquisition should proceed at a faster rate (Anderson, 2003). Learners' metacognition can affect the process and the outcome of their learning (Anderson, 2003; Bolitho et al., 2003).

Metacognition refers to listener awareness of the cognitive processes involved in comprehension, and the capacity to oversee, regulate, and direct these processes (Goh, 2008). Metacognition is defined as a construct that refers to thinking about one's thinking or the human ability to be conscious of one's mental processes (Rahimi \& Katal, 2011). It means that when learners are aware or conscious of their learning 1 process they have implemented metacognitive strategy. These strategies include five types of strategies, i.e., problem-solving, planning and evaluation, mental translation, person knowledge, and directed attention (Vandergrift \& Goh,2012). Metacognitive strategies help students understand the way they learn and the steps they take. In this strategy students are involved in thinking about the process of learning while they are planning, monitoring, and evaluating their own learning, which reflect in pre-tasks, on task and post-task activities (Holden, 2004).

Based on the background, it is needed to investigate the students listening strategies awareness and the listening difficulties among the second semester students at Faculty of Letter of Universitas Pamulang.
A goal of language is to enable people to communicate and interact with society. Communication engages 4 skills: listening, speaking, reading and writing. However, listening skill holds most important role in communication. Holden (2004) convey that adults spend $40-50 \%$ of their communication time engaged in listening, and $50 \%$ others for writing, speaking and reading. That shows how listening give great contribution on communication. It can be inferred that it is important for teacher to concern how listening take place in the classroom or learning-teaching process. It is also important for students to knows how their listening skill ability level, identifying their listening problems, having the solutions for their listening problems and having listening strategy to improve their listening skill.

Newton and Nation (2009) state that listening was traditionally seen as a passive process by which the listener receives information sent by a speaker. Furthermore, they add that more recent models view listening as a much more active and interpretive process in which the message is not fixed but is created in the interactional space between participants. Meanings are shaped by context and constructed by the listener through the act of interpreting meaning rather than receiving it intact (Lynch and Mendelsohn, 2002). It means that listening is not only the matter of receiving the information, but it involves the ability to interpret the messages and give an appropriate response and feedback to the speaker.

Strategy is a way or activity to enhance listening input. There are some types of learning strategy. Buck (2001) identifies two kinds of strategies in listening:

Cognitive strategies: Mental activities related to comprehending and storing input in working memory or long-term memory for later retrieval

Comprehension processes: Associated with the processing of linguistic and nonlinguistic input

Storing and memory processes: Associated with the storing of linguistic and nonlinguistic input in working memory or long-term memory

Using and retrieval processes: Associated with accessing memory, to be readied for output 
2. Metacognitive strategies: Those conscious or unconscious mental activities that perform an executive function in the management of cognitive strategies

O'Malley and Chamot (1990) propose three main types of strategies, namely, cognitive, metacognitive, social strategies. The metacognitive strategies are kinds of actions whereby learners are consciously attentive to a spoken text, and monitor and evaluate their comprehension of the text. The cognitive strategies consist of an array of sub-techniques, e.g., elaboration, inferencing, and translation while the social strategies include 'question for clarification' and 'cooperation'.

In addition, Oxford (1990) also classifies language learning strategies into direct strategies (memory, cognitive, and compensation), and indirect strategies (metacognitive, affective, and social). She defines direct strategy as language learning strategy that directly involves the target language. This strategy requires mental process. follows:

Oxford outlines direct strategies as

a. Memory strategies. The strategies which also known as mnemonics, are divided into four sets: Creating mental images, applying images and sounds, reviewing well, and employing actions.

b. Cognitive strategies. These strategies may vary from repeating to analyzing expressions to summarizing, have a unified function, namely to manipulate or transform the target language by the learner. Cognitive strategies fall into four sets: Practicing, receiving and sending messages, analyzing and reasoning, and creating structure for input and output.

c. Compensation strategies allow learners to use the target language for either comprehension or production despite their inadequate knowledge of grammar and vocabulary. Compensation strategies are grouped into two sets: Guessing in Listening and Reading also known as "inferencing", and overcoming limitations in Speaking and Writing.

follows:

While indirect strategies are outlined as

a. Metacognitive, that refers to beyond or with cognitive, accommodates learners with ways to coordinate their learning process. Metacognitive strategies are divided into three sets: planning your learning, centering your learning, and evaluating your learning.

b. The affective field, which is extremely hard to describe, refers to emotions, attitudes, and motivations. Affective strategies include three sets: lowering your anxiety, encouraging yourself, and taking your emotional temperature.

c. Language is a communication that occurs between and among people. Thus, learning a language involves other people, and appropriate strategies are necessary in this learning process. Social strategies are clustered into three groups: Asking questions, cooperating with others, and empathizing with others.

Metacognition refers to listener awareness of the cognitive processes involved in comprehension, and the capacity to oversee, regulate, and direct these processes (Goh, 2008). Metacognition is defined as a construct that refers to thinking about one's thinking or the human ability to be conscious of one's mental processes (Rahimi $\&$ Katal, 2011). It means that when learners aware or conscious of their learning process they have implemented metacognitive strategy. These strategies include five types of strategies, i.e., problem-solving, planning and evaluation, mental translation, person knowledge, and directed attention (Vandergrift \& Goh,2012).

Metacognitive strategies are being the most essential in developing learners' skills (Anderson, 1991), which can activate thinking and possess the power to guide and enhance the learning performance (Anderson, 2003). This stance is supported by Goh (2002) who argues that learners' metacognitive awareness correlates with the effective learning process.

The metacognitive strategies in listening reveals that to the actions that learners use consciously while listening to a spoken text seriously. Metacognitive strategies deal with knowing about learning. It shows that learners learn how to learn with metacognitive strategies. By the assistance of this language learning strategy, learners are engaged in thinking about learning process while they are planning, monitoring, and evaluating their own learning, exactly like pre-tasks activities (Holden, 2004). Learners check-up and appraise their comprehension of the listening text by the use of metacognitive strategies.

Specifically, Buck (2001) determines metacognitive strategy into: 
- Assessing the situation: Taking stock of relatively clear to listeners. However, in informal conditions surrounding a language task situations, signals such as gestures, increased by assessing one's own knowledge, one's loudness, or a clear change of pitch are very available internal and external resources, ambiguous, especially to L2 learners.

and the constraints of the situation before

The fifth is challenging to concentrate in a engaging in a task

- Monitoring: Determining the known that in listening, even a slight break or a effectiveness of one's own or another's wander in attention can improve comprehension. performance while engaged in a task If it is found that the topic is interesting, it makes

- Self-evaluating: Determining the learners easier to focus on and follow the passage. effectiveness of one's own or another's However, they sometimes feel that listening is performance after engaging in the activity very challenging even when they are interested in

- Self-testing: Testing oneself to the topic because it requires a lot of effort to determine the effectiveness of one's own figure out the meaning intended by the speaker.

language use or the lack thereof

The sixth is learning habits. Learning habit

Focused on the classroom such as a motivation to

Some studies of listening strategies understand the meaning of every word. Teachers (Amirian \& Rate bi, 2013; Rahimini \& Katal, oftentimes want students to understand every word 2010) used MALQ questionnaire to investigate they encounter while listening by pronouncing and students listening strategy. MALQ is repeating words clearly and carefully, and by questionnaire which was developed and speaking slowly and so forth. As a result, students validated Vandergrift, Goh, Mareschal, \& tend to feel worried when they fail to recognize Tafaghodatari, (2006).

what a particular word means and may further be

There are many factors that affect listening discouraged by the failure. Students should input or listening process while the role of specific therefore, be instructed to tolerate incompleteness factors has also been examined. Underwood (1989) and vagueness of understanding. points out seven factors that could affect listening The last is comprehension problems. It skill input and process. arises when students lack contextual knowledge.

First factor is the speaker speed. Even if students can understand the main idea of the Underwood (1989) states that many language text, they may still find it difficult to comprehend learners believe that the greatest difficulty with the whole meaning of the text. Listeners from listening comprehension, as opposed to reading different cultural backgrounds can also misinterpret comprehension, is that listener cannot control how nonverbal cues such as facial expressions, gestures, quickly a speaker. The researchers were done by or tone of voice.

Zhao (1997) and Hayati (2010) also reveal that one

Hamouda (2013) investigated Saudi of the listening difficulties is caused by speaker students in listening comprehension problems and speech speed rate. found that the factors which facilitate listening are

The second is the possibility to repeat or accent, pronunciation, speed of speech, insufficient replay the recorder. It is the teacher who decides vocabulary, different accents of speakers, lack of whether to reply the recorder or not. It is based on concentration, anxiety, and bad quality of recording the students' needs and the strategy in teaching were the major listening comprehension problems itself. Hard for the teacher to judge whether or not encountered by EFL Saudi learners.

the students have understood any particular section of what they have heard (Underwood, 1989).

\section{METHODOLOGY}

The third is the small size of the learner The current research employs a combination vocabulary frequently impedes listening of a descriptive quantitative and qualitative study by comprehension. The speaker does not always use including survey items aimed at demanding words the listener knows. Sometimes when objective responses as well as qualitative openlisteners encounter a new word, they stop to figure ended question responses from the participants. The out the meaning of that word, and they therefore, triangulation of data has the potential to reduce the miss the next part of the speech. biases inherent in one method while enhancing the

The fourth is listeners may not recognize validity of inquiry (Mackey \& Gass, 2005).

the signals that the speaker is using to move from one point to another, give an example, or repeat a The participants of this study were 131 point. Discourse second semester students at Faculty formal situations (i.e., firstly, and after that) are 
2017/2018. Out of 305 students of the population, the interpretation of the quantitative data. The 131 students were chosen as the samples based on questionnaire was conducted on a one-on-one basis the random sampling. The participants consist of from March 2018 until May 2018 using online 99 females and 32 males. questionnaire method.

\begin{tabular}{l|l|r|r|r|r}
\hline \multicolumn{2}{l|}{ Table 1. Gender } \\
\hline \multirow{3}{*}{} & Frequency & Percent & $\begin{array}{c}\text { Valid } \\
\text { Percent }\end{array}$ & $\begin{array}{c}\text { Cumulative } \\
\text { Percent }\end{array}$ \\
\hline \multirow{3}{*}{ Valid } & Female & 99 & 75.6 & 75.6 & 75.6 \\
\cline { 2 - 6 } & Male & 32 & 24.4 & 24.4 & 100.0 \\
\cline { 2 - 6 } & Total & 131 & 100.0 & 100.0 & \\
\hline
\end{tabular}

\section{Technique of Data Analysis}

Quantitative data was analyzed using the Statistical Package for Social Sciences (SPSS version 20). Frequencies and means were used to analyze single items. Qualitative data analysis followed the five analytical-strategy steps proposed

In order to gather the required data, by Schmidt (2004). The researcher categorized the Metacognitive Awareness Listening Questionnaire data result of second instrument. It was an open(MALQ) (Vandergrift, et al., 2006) was employed. ended questionnaire to elicit listening problems The questionnaire consists of 21 items that assesses encountered by the students. After the data were language learners' awareness and perceived use of categorized, the researcher analyzed and interpreted listening strategies. Each item is rated on a six- the data.

point Likert scale rating from 1 (strongly disagree) to 6 (strongly agree) without a neutral point so that respondents could not hedge. MALQ comprises of five factors. It includes planning and evaluation (5 items), problem-solving (6 items), mental translation (3 items), directed attention (4 items and person knowledge (3 items),). The validity of the questionnaire has been explored by the developers using both exploratory and confirmatory analysis by a large sample of different foreign language learners (Vandergrift, et al., 2006).

The second data gathering instrument which was employed in this study was open-ended questionnaire. The purpose of the questionnaire was to know learners' listening problem. Learners' problems were categorized into; listening problems related to the content of the listening skill, listening problems related to the linguistic features, listening problems caused by failure to concentrate, listening problems related to psychological characteristics, problems related to the listener, problems related to the speaker, problems related to the physical setting and other listening problems if any.

In this research, the researcher used Metacognitive Awareness Listening Questionnaire (MALQ) developed and validated by Vandergrift et al. (2006) to assess language learners' awareness of listening strategies. The questionnaire contains 21 items and each item is rated on a five-point Likert scale rating from 1 (strongly disagree) to 5 (strongly agree). MALQ consists of five factors including problem-solving (six items), planning and evaluation (five items), mental translation (three items), person knowledge (three items), and directed attention (four items).

The second instrument is open-ended questionnaire. The questionnaire conducted after the MALQ questionnaires were collected. The aim was to gather qualitative data to back up and assist

\section{FINDINGS AND DISCUSSION}

This section focuses on the discussion of the research findings. The findings include the results of the student listening strategy using MALQ and questionnaire about listening problem they faced.

Finding I: Students Metacognitive Strategy Awareness

Table 2

Descriptive statistic of each aspect of MALQ

\begin{tabular}{|c|c|c|c|c|c|c|c|c|}
\hline & \multirow[b]{2}{*}{$\mathrm{N}$} & \multirow[b]{2}{*}{$\mathrm{R}$} & \multirow[b]{2}{*}{ Min } & \multirow[b]{2}{*}{ Max } & \multirow[b]{2}{*}{ Sum } & \multicolumn{2}{|c|}{ Mean } & \multirow[b]{2}{*}{ SD } \\
\hline & & & & & & Statistic & $\begin{array}{l}\text { Std. } \\
\text { Error }\end{array}$ & \\
\hline $\begin{array}{l}\text { 1. Before I start } \\
\text { to listen, I have } \\
\text { a plan in my } \\
\text { head for how I } \\
\text { am going to } \\
\text { listen. }\end{array}$ & 131 & 5 & 1 & 6 & 577 & 4.40 & .126 & 1.440 \\
\hline $\begin{array}{l}\text { 2. I focus } \\
\text { harder on the } \\
\text { text when I } \\
\text { have trouble } \\
\text { understanding. }\end{array}$ & 131 & 5 & 1 & 6 & 647 & 4.94 & .117 & 1.340 \\
\hline $\begin{array}{l}\text { 3. I find that } \\
\text { listening in } \\
\text { English is more } \\
\text { difficult than } \\
\text { reading, } \\
\text { speaking, or } \\
\text { writing in } \\
\text { English. }\end{array}$ & 131 & 5 & 1 & 6 & 553 & 4.22 & .138 & 1.575 \\
\hline $\begin{array}{l}\text { 4. I translate in } \\
\text { my head as I } \\
\text { listen. }\end{array}$ & 131 & 5 & 1 & 6 & 610 & 4.66 & .109 & 1.251 \\
\hline $\begin{array}{l}5 . \text { I use the } \\
\text { words I } \\
\text { understand to } \\
\text { guess the } \\
\text { meaning of the } \\
\text { words I don't } \\
\text { understand. }\end{array}$ & 131 & 5 & 1 & 6 & 638 & 4.87 & .108 & 1.237 \\
\hline
\end{tabular}


Note:

$\mathrm{N}=$ number of students; $\mathrm{R}=$ range; $\mathrm{Min}=$ minimum; $\mathrm{Max}=$ maximum; $\mathrm{SD}=$ Standard Deviation

Table 2 summarized 131 university student participants means and standard deviation of each item on MALQ. The mean of MALQ ranged from 2.31 to 5.15 , implying the lowest statement and the highest statement.

Table 3. Distribution of Mean Score on MALQ 


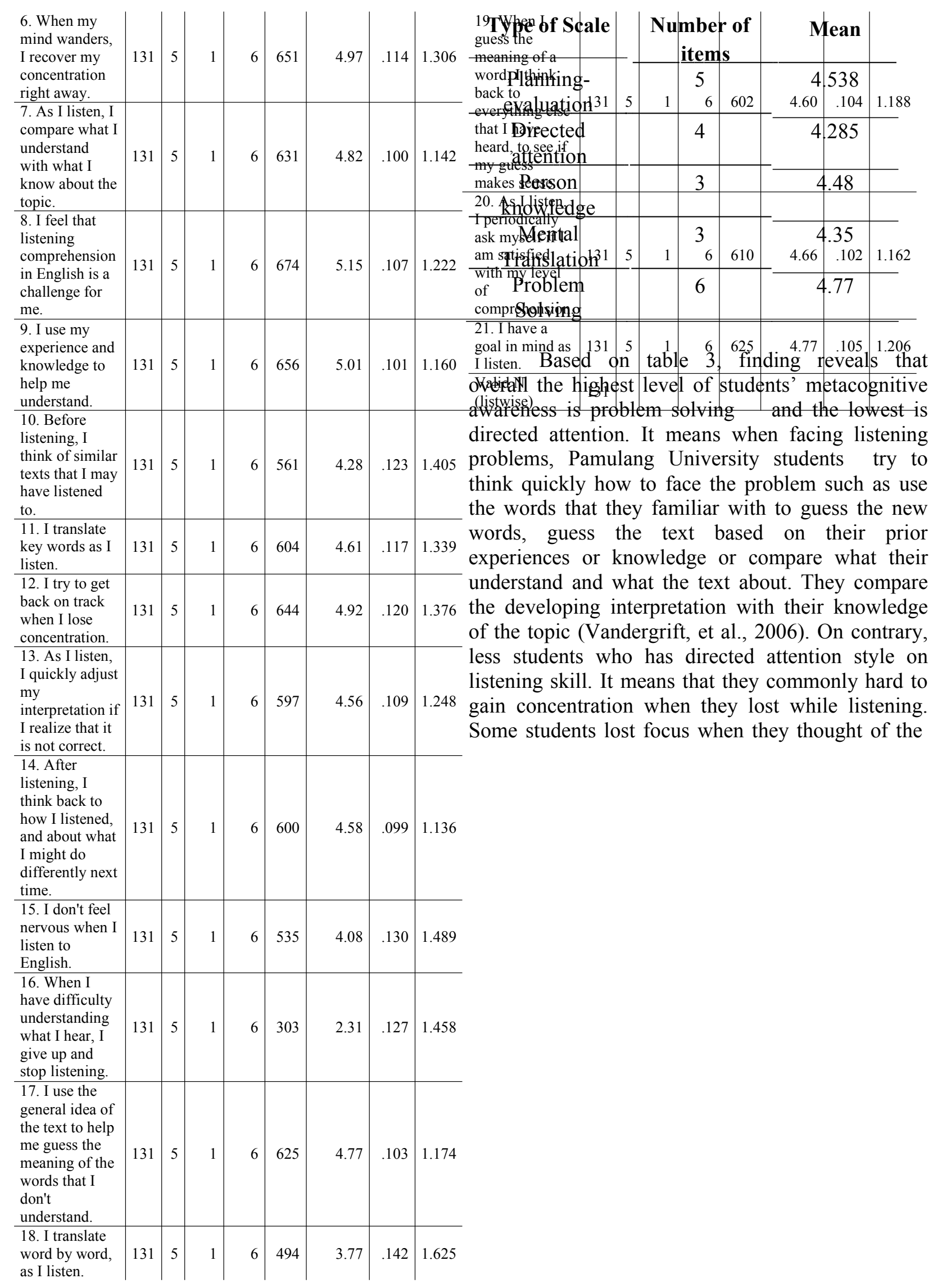


answer of previous question, or could not process the previous information while another information come, some students lost concentration because of the noise that made by their friends. Even though ${ }^{15}$ they tried to regain the concentration, they are-

\begin{tabular}{|l|r|r|r|r|r|r|r}
$\begin{array}{l}\text { in English is a } \\
\text { challenge for } \\
\text { me. }\end{array}$ & & & & & & & \\
$\begin{array}{ll}\text { I don't feel } \\
\text { nervous when I }\end{array}$ & 7 & 3 & 7 & 20 & 34 & 60 & 4.08 \\
\cline { 2 - 6 } $\begin{array}{l}\text { listen to } \\
\text { English. }\end{array}$ & $\begin{array}{r}5.3 \\
\%\end{array}$ & $\begin{array}{r}2.3 \\
\%\end{array}$ & $\begin{array}{r}5.3 \\
\%\end{array}$ & $\begin{array}{r}15.3 \\
\%\end{array}$ & $\begin{array}{r}26.0 \\
\%\end{array}$ & $\begin{array}{r}45.8 \\
\%\end{array}$ & \\
\hline \multicolumn{7}{c}{ Total } \\
\hline
\end{tabular}


Table 5. Direct Attention

\begin{tabular}{|c|c|c|c|c|c|c|c|c|}
\hline $\begin{array}{c}\text { No. } \\
\text { of } \\
\text { data }\end{array}$ & $\begin{array}{c}\text { Strategy/ } \\
\text { Belief/ } \\
\text { Perception }\end{array}$ & 1 & 2 & 3 & 4 & 5 & 6 & Mean \\
\hline \multirow[t]{2}{*}{2} & \multirow{2}{*}{$\begin{array}{l}\text { I focus } \\
\text { harder on } \\
\text { the text } \\
\text { when I } \\
\text { have } \\
\text { trouble } \\
\text { understandi } \\
\text { ng. }\end{array}$} & 4 & 5 & 11 & 18 & 30 & 63 & \multirow[t]{2}{*}{4.94} \\
\hline & & $\begin{array}{r}3.1 \\
\%\end{array}$ & $\begin{array}{r}3.8 \\
\%\end{array}$ & $\begin{array}{r}8.4 \\
\%\end{array}$ & $\begin{array}{r}13.7 \\
\%\end{array}$ & $\begin{array}{r}22.9 \\
\%\end{array}$ & $\begin{array}{r}48.1 \\
\%\end{array}$ & \\
\hline \multirow[t]{2}{*}{6} & \multirow{2}{*}{$\begin{array}{l}\text { When my } \\
\text { mind } \\
\text { wanders, I } \\
\text { recover my } \\
\text { concentrati } \\
\text { on right } \\
\text { away. }\end{array}$} & 6 & 2 & 6 & 23 & 33 & 61 & \multirow[t]{2}{*}{4.97} \\
\hline & & $\begin{array}{r}4.6 \\
\%\end{array}$ & $\begin{array}{r}1.5 \\
\%\end{array}$ & $\begin{array}{r}4.6 \\
\%\end{array}$ & $\begin{array}{r}17.6 \\
\%\end{array}$ & $\begin{array}{r}25.2 \\
\%\end{array}$ & $\begin{array}{r}46.6 \\
\%\end{array}$ & \\
\hline \multirow[t]{2}{*}{12} & \multirow{2}{*}{$\begin{array}{l}\text { I try to get } \\
\text { back on } \\
\text { track when } \\
\text { I lose } \\
\text { concentrati } \\
\text { on. }\end{array}$} & 7 & 3 & 7 & 20 & 34 & 60 & \multirow[t]{2}{*}{4.92} \\
\hline & & $\begin{array}{r}5.3 \\
\%\end{array}$ & $\begin{array}{r}2.3 \\
\%\end{array}$ & $\begin{array}{r}5.3 \\
\%\end{array}$ & $\begin{array}{r}15.3 \\
\%\end{array}$ & $\begin{array}{r}26.0 \\
\%\end{array}$ & $\begin{array}{r}45.8 \\
\%\end{array}$ & \\
\hline \multirow[t]{2}{*}{16} & \multirow{2}{*}{$\begin{array}{l}\text { When I } \\
\text { have } \\
\text { difficulty } \\
\text { understandi } \\
\text { ng what I } \\
\text { hear, I give } \\
\text { up and stop } \\
\text { listening. }\end{array}$} & 9 & 12 & 22 & 31 & 30 & 27 & \multirow[t]{2}{*}{2.31} \\
\hline & & $\begin{array}{r}6.9 \\
\%\end{array}$ & $\begin{array}{r}9.2 \\
\%\end{array}$ & $\begin{array}{r}16.8 \\
\%\end{array}$ & $\begin{array}{r}23.7 \\
\%\end{array}$ & $\begin{array}{r}22.9 \\
\%\end{array}$ & $\begin{array}{r}20.6 \\
\%\end{array}$ & \\
\hline \multicolumn{8}{|c|}{ Total } & 4.285 \\
\hline
\end{tabular}

The table above reveals a finding of
On table 6 above, we can infer that more than $50 \%$ of students experience that the other three skills (speaking, reading or writing) are easier than listening. Then, they found that listening is challenging. However, they would feel nervous when they listen to English (statement 15).

Table 7. Mental Translation

\begin{tabular}{|c|c|c|c|c|c|c|c|c|}
\hline $\begin{array}{c}\text { No. } \\
\text { of } \\
\text { data }\end{array}$ & $\begin{array}{c}\text { Strategy/ } \\
\text { Belief/ } \\
\text { Perception }\end{array}$ & 1 & 2 & 3 & 4 & 5 & 6 & Mean \\
\hline \multirow{2}{*}{4} & \multirow[t]{2}{*}{$\begin{array}{l}\text { I translate } \\
\text { in my head } \\
\text { as I listen. }\end{array}$} & 4 & 4 & 13 & 29 & 43 & 38 & \multirow[t]{2}{*}{4.66} \\
\hline & & $\begin{array}{r}3.1 \\
\%\end{array}$ & $\begin{array}{r}3.1 \\
\%\end{array}$ & $\begin{array}{r}9.9 \\
\%\end{array}$ & $\begin{array}{r}22.1 \\
\%\end{array}$ & $\begin{array}{r}32.8 \\
\%\end{array}$ & $\begin{array}{r}29.0 \\
\%\end{array}$ & \\
\hline \multirow{2}{*}{11} & \multirow[t]{2}{*}{$\begin{array}{l}\text { I translate } \\
\text { key words } \\
\text { as I listen. }\end{array}$} & 5 & 6 & 13 & 27 & 40 & 40 & \multirow[t]{2}{*}{4.61} \\
\hline & & $\begin{array}{r}3.8 \\
\%\end{array}$ & $\begin{array}{r}4.6 \\
\%\end{array}$ & $\begin{array}{r}9.9 \\
\%\end{array}$ & $\begin{array}{r}20.6 \\
\%\end{array}$ & $\begin{array}{r}30.5 \\
\%\end{array}$ & $\begin{array}{r}30.5 \\
\%\end{array}$ & \\
\hline \multirow[b]{2}{*}{18} & \multirow{2}{*}{$\begin{array}{l}\text { I translate } \\
\text { word by } \\
\text { word, as I } \\
\text { listen. }\end{array}$} & 14 & 18 & 25 & 28 & 19 & 27 & \multirow[t]{2}{*}{3.77} \\
\hline & & $\begin{array}{r}10.7 \\
\%\end{array}$ & $\begin{array}{r}13.7 \\
\%\end{array}$ & $\begin{array}{r}19.1 \\
\%\end{array}$ & $\begin{array}{r}21.4 \\
\%\end{array}$ & $\begin{array}{r}14.5 \\
\%\end{array}$ & $\begin{array}{r}20.6 \\
\%\end{array}$ & \\
\hline \multicolumn{8}{|c|}{ Total } & 4.35 \\
\hline
\end{tabular}

Note: 1 to 6 indicate a frequency from Strongly Disagree to Strongly Agree

Finding reveals (table 7) that $41 \%$ of directed attention type. The majority of students students translated as they listen (statement 4). They have no big deal with concentration when tried to translate key word of the text when they listening. Most of them able to regain the listened, but almost $50 \%$ of them translated word concentration when they lost the concentration by word as they listened (statement 18). It means while listening (statement 6 and 12). However, they used their set of vocabulary and their own more than $50 \%$ students agreed that they would knowledge and understanding to get the general give up when they faced difficulties on meaning of new words. Fewer students who could understanding what they heard (statement 16) even seize the whole words of the text, they mostly hold though they tried harder when have trouble the key words as they listen and translate them to understanding (statement 2). help understanding the text.

Table 6. Person knowledge

\begin{tabular}{|c|c|c|c|c|c|c|c|c|}
\hline $\begin{array}{l}\text { No of } \\
\text { data }\end{array}$ & $\begin{array}{l}\text { Strategy/Belief } \\
\text { /Perception }\end{array}$ & 1 & 2 & 3 & 4 & 5 & 6 & Mean \\
\hline \multirow{2}{*}{3} & \multirow{2}{*}{$\begin{array}{l}\text { I find that } \\
\text { listening in } \\
\text { English is more } \\
\text { difficult than } \\
\text { reading, } \\
\text { speaking, or } \\
\text { writing in } \\
\text { English. }\end{array}$} & 6 & 17 & 23 & 21 & 24 & 40 & \multirow[t]{2}{*}{4.22} \\
\hline & & $\begin{array}{r}4.6 \\
\%\end{array}$ & $\begin{array}{r}13.0 \\
\%\end{array}$ & $\begin{array}{r}17.6 \\
\%\end{array}$ & $\begin{array}{r}16.0 \\
\%\end{array}$ & $\begin{array}{r}18.3 \\
\%\end{array}$ & $\begin{array}{r}30.5 \\
\%\end{array}$ & \\
\hline \multirow[b]{2}{*}{8} & \multirow{2}{*}{$\begin{array}{l}\text { I feel that } \\
\text { listening } \\
\text { comprehension }\end{array}$} & 5 & 1 & 6 & 15 & 35 & 69 & \multirow[t]{2}{*}{5.15} \\
\hline & & $\begin{array}{r}3.8 \\
\%\end{array}$ & $.8 \%$ & $\begin{array}{r}4.6 \\
\%\end{array}$ & $\begin{array}{r}11.5 \\
\%\end{array}$ & $\begin{array}{r}26.7 \\
\%\end{array}$ & $\begin{array}{r}52.7 \\
\%\end{array}$ & \\
\hline
\end{tabular}

Table 8. Problem Solving

\begin{tabular}{c|l|l|l|l|l|l|l|l}
\hline $\begin{array}{c}\text { No. } \\
\text { of } \\
\text { data }\end{array}$ & $\begin{array}{l}\text { Strategy/ } \\
\text { Belief/ } \\
\text { Perception }\end{array}$ & $\mathbf{1}$ & $\mathbf{2}$ & $\mathbf{3}$ & $\mathbf{4}$ & $\mathbf{5}$ & $\mathbf{6}$ & Mean \\
\hline \multirow{2}{*}{5} & $\begin{array}{l}\text { I use the } \\
\text { words I } \\
\text { understand } \\
\text { to guess the } \\
\text { meaning of } \\
\text { the words I } \\
\text { don't } \\
\text { understand. }\end{array}$ & $\begin{array}{r}2.3 \\
\%\end{array}$ & $\begin{array}{r}2.3 \\
\%\end{array}$ & $\begin{array}{r}9.9 \\
\%\end{array}$ & $\begin{array}{r}16.8 \\
\%\end{array}$ & $\begin{array}{r}29.0 \\
\%\end{array}$ & $\begin{array}{r}39.7 \\
\%\end{array}$ & \multirow{2}{*}{4.87} \\
\hline
\end{tabular}


As I listen,

I compare

what I

2

38

45

understand

with what I
1. The speaker speed ( Underwood, 1989; Zhao, 1997 ; \& Hayati, 2010)

4.82 


\begin{tabular}{|c|c|c|c|c|c|c|c|c|}
\hline & $\begin{array}{l}\text { know about } \\
\text { the topic. }\end{array}$ & $\begin{array}{r}1.5 \\
\%\end{array}$ & $\begin{array}{r}2.3 \\
\%\end{array}$ & $\begin{array}{r}6.9 \\
\%\end{array}$ & $\begin{array}{r}26.0 \\
\%\end{array}$ & $\begin{array}{r}29.0 \\
\%\end{array}$ & $\begin{array}{r}34.4 \\
\%\end{array}$ & \\
\hline 9 & $\begin{array}{l}\text { I use my } \\
\text { experience } \\
\text { and } \\
\text { knowledge } \\
\text { to help nte }\end{array}$ & 2 & 4 & 7 & 22 & 39 & 57 & 5.01 \\
\hline \multirow[b]{2}{*}{13} & understand. & $\begin{array}{r}1.5 \\
\%\end{array}$ & $\begin{array}{r}3.1 \\
\%\end{array}$ & $\begin{array}{r}5.3 \\
\%\end{array}$ & $\begin{array}{r}16.8 \\
\%\end{array}$ & $\begin{array}{r}29.8 \\
\%\end{array}$ & $\begin{array}{r}43.5 \\
\%\end{array}$ & \multirow{4}{*}{4.56} \\
\hline & $\begin{array}{l}\text { As I listen, } \\
\text { I quickly } \\
\text { adjust my } \\
\text { interpretati }\end{array}$ & 4 & 4 & 14 & 37 & 37 & 35 & \\
\hline \multirow[b]{2}{*}{17} & $\begin{array}{l}\text { on if I } \\
\text { realize that } \\
\text { it is not } \\
\text { correct. }\end{array}$ & $\begin{array}{r}3.1 \\
\%\end{array}$ & $\begin{array}{r}3.1 \\
\%\end{array}$ & $\begin{array}{r}10.7 \\
\%\end{array}$ & $\begin{array}{r}28.2 \\
\%\end{array}$ & $\begin{array}{r}28.2 \\
\%\end{array}$ & $\begin{array}{r}26.7 \\
\%\end{array}$ & \\
\hline & $\begin{array}{l}\text { I use the } \\
\text { general idea } \\
\text { of the text } \\
\text { to help me }\end{array}$ & 3 & 1 & 13 & 33 & 37 & 44 & \\
\hline \multirow{4}{*}{19} & \multirow{2}{*}{$\begin{array}{l}\text { guess the } \\
\text { meaning of } \\
\text { the words } \\
\text { that I don't } \\
\text { understand. } \\
\text { When I } \\
\text { guess the } \\
\text { meaning of } \\
\text { a word, I }\end{array}$} & $\begin{array}{r}2.3 \\
\%\end{array}$ & $.8 \%$ & $\begin{array}{r}9.9 \\
\%\end{array}$ & $\begin{array}{r}25.2 \\
\%\end{array}$ & $\begin{array}{r}28.2 \\
\%\end{array}$ & $\begin{array}{r}33.6 \\
\%\end{array}$ & \multirow[t]{2}{*}{4.77} \\
\hline & & 4 & 1 & 14 & 41 & 36 & 35 & \\
\hline & \multirow{2}{*}{$\begin{array}{l}\text { think back } \\
\text { to } \\
\text { everything } \\
\text { else that I } \\
\text { have heard, } \\
\text { to see if my } \\
\text { guess } \\
\text { makes } \\
\text { sense. }\end{array}$} & $\begin{array}{r}3.1 \\
\% \\
\end{array}$ & $.8 \%$ & $\begin{array}{r}10.7 \\
\%\end{array}$ & $\begin{array}{r}31.3 \\
\%\end{array}$ & $\begin{array}{r}27.5 \\
\%\end{array}$ & $\begin{array}{r}26.7 \\
\%\end{array}$ & 4.60 \\
\hline & & & Total & & & & & 4.77 \\
\hline
\end{tabular}

Note: 1 to 6 indicate a frequency from Strongly Disagree to Strongly Agree

From table 8 above, the finding reyeals tost some information.

that majority of students used their knowledge

about the topic when they did not understand what 3. The small size of the learner vocabulary.

they heard (statement $7 \& 9$ ). They tried to guess

the meaning of the text or words when they have no idea about the text (statement 5, 17 \& 19). their needs vocabulary to comprehend the text. When interpretation was not correct, they adjusted their students mastered some vocabulary from any topic, interpretation (statement 13).

\section{Findings II: Listening Problem Encountered by} Students

Question:

What factors make listening comprehension difficult for you? Mention as many as you can.

Through the survey questionnaire, the respondents reveal many problems related to Students 3: Speed of the sentence, The word I don't listening that may arise from their inability to recognize the main words in listening comprehension to understand the spoken text from the first listening. The listening problems that they faced is categorized into eight categorize.
It was found that 41 students of 131 claim that one of big listening problem that they face is the speed of speaker. The speaker speaks too fast, so the even they lost whole information. Here are some examples of the students comment:

Student 1: ...The sound was not clear, the speaker spoke too fast, didn't understand the meaning of some words.

Student 2: The accent, can't understand some words, the speaker talk too fast, so hard to concentration

Student 3: when people talk too fast, that what makes me difficult to understand

The speed of speaker also affects another factor such as concentration and comprehension. The faster speaker talk, the harder they get concentration and comprehension.

2. The possibility to repeat or replay the recorder (Underwood, 1989)

Almost no students were found who have problem with recorder replaying. Most lecturer will replay the recorder while practice listening at classroom. It made students have another chance to listen the recorder. However, one student revealed that there is no replay recorder at exam makes them it made them easily to understand. 40 students out of 131 students who felt that lack of vocabulary bother their understanding of the text.

Student 1: I feel nervous when I listen to English and I think lack of vocabulary, poorsounding pronunciation, and frequent loss of concentration.

Student 2: The new vocabulary and different pronunciation. understand, Which sentence is too long, The word is not clear, confusing words students could not process every part of information 
4. The listeners' ability to recognize the signals Student 2: The media condition that the speaker is using to move from one Student 3: Sound factor, because sometimes the point to another, give an example, or repeat a point. recorder sounds terrible, and the pronunciation isn't heard at all, and the

In this problem aspect only three students who realize that the move of point to point also affect their listening comprehend. The other students could be having no problem with the signal movement or they might did not realize the signal movement. accent too.

5. Challenging to concentrate in a foreign language.

The other problem is concentration. There are many students who realized that be bothered with the condition around them such as noisy which made by their friends or thinking about the answer. When they lost concentration, it was hard to finish the listening exercise.

Student 1: Lost concentration when they are talking using different accent

Student 2: ... because noisy, loss of focus and..

Student 3: ... loses concentration due to thinking of the previous answer unanswered...

6. Learning habits.

Some students used to listening music or watching English movies. The finding reveals only few students who lack of practice listening 3 . English.

7. The seventh is accent and pronunciation.

Unclear pronunciation and accent cause much difficulty for most of students. It was found that 50 students experienced difficulty related to pronunciation and speaker accent. Some of them did not used to British accent which mostly uses in the classroom.

Student 1: The accent especially for British and Aussie. Because mostly I've been entertained by American accent, such as their movies and songs...

Student 2: It's unordinary in everyday especially if using British accent...

\section{Another factor}

Besides all of the factors above, the students also mention another problem related to listening such as the audio or recorder and physical ear health.

Students 1: maybe my ear is problematic and may my mind messed up (not focused) and I also often forget vocabulary 
certain key words and give them practice since lack of vocabulary becomes a great obstacle to them in listening comprehension. Guessing word from the context would be better to ask to ask them while listening activity take place than ask them to look up at dictionary or explaining them directly. It would help them to get used to with new vocabulary with another topic in another listening.

4. Use various media with different accent since they have great obstacle on accent and pronunciation. It could be movies, conversations, songs, or news with American, British, Australian or the other English accent.

5. Give them feedback toward their understanding of text while listening. It is also needed to check their understanding of various accents. It is useful to see if there any improvement or help them preparing with Holden, appropriate strategy.

6. Teacher should check and make sure the recorder is in good condition before using it in classroom.

The next research needs to be carried out with larger sample.

\section{REFERENCES}

Ahmed, A,. et al. (2013). EFL Learners' Listening Comprehension and Awareness of Metacognitive Strategies: How Are They Related? International Education Studies, $6,1-9$.

Anderson, N. (1991). Individual differences in strategy use in second language reading and testing. Modern Language Journal, 75 , 406-472. http://dx.doi.org/10.1111/ j.15404781.1991.tb05384.

Anderson, N. (2003). Metacognitive reading strategies increase L2 performance. The Language Teacher, 27, 20-22.

Anderson, N. J. (2003). Metacognitive reading strategies increase L2 performance. The Language Teacher, 27, 20-22.

Bolitho, R., Carter, R., Hughes, R., Ivanic, R., Masuhara, H., and Tomlinson, B. (2003). Ten questions about language awareness. ELT Journal,57(3), 251-260.

Buck, G. (2001). Assessing Listening. Cambridge: Cambridge University Pres.

Goh, C. (2002). A cognitive perspective on language learners' listening comprehension problems. System, 28,55-75. http://dx.doi.org/10.1016/S0346-
251X(99)00060-3

Goh, C. (2008). Exploring listening comprehension tactics and their interaction patterns. System, $30(2)$, 185-206. http://dx.doi.org/10.1016/S0346251X(02)00004-0

Hamouda, A. (2013). An Investigation of Listening Comprehension Problems Encountered by Saudi Students in the EL Listening Classroom. International Journal of Academic Research in Progressive Education and Development. 2. 1-43

Hayati, A. (2010). The Effect of Speech Rate on Listening Comprehension of EFL learners. SciRP, 2, 107-114. http://file.scirp.org/pdf/ CE20100200006 10 837161.pdf

, W.R. (2004). Facilitating Listening Comprehension: Acquiring Successful Strategies. Bulletin of Hokuriku University, 28, 257-266.

Leonardo De Valoes. (2014). Importance of Language - Why Learning a Second Language is Important. Retrieved at: http://www.trinitydc.edu/continuingeducation/2014/02/26/importance-oflanguage-why-learning-a-second-languageis-important/ on 2 September 2017

Liu, H. (2008). A Study of the Interrelationship between Listening Strategy Use, Listening proficiency, And Learning Style. ARECLS, 8, 84-104

O'Malley, J., \& Chamot, A. (1990). Learning Strategies in Second Language Acquisition. Cambridge: Cambridge University Press. http://dx.doi.org/10.1017/CBO97811395244 $\underline{90}$

Oxford, R. L. (1990). Language learning strategies: What every teacher should know. Boston: Heinle and Heinle.

Newton, J \& Nation, I.S.P. (2009). Teaching ESL Listening and Speaking. New York : Routledge

Ratebi, Z \& Amirian, Z. (2013). Use of Metacognitive Strategies in Listening Comprehension by Iranian University Students Majoring in English: A Comparison between High and Low Proficient Listeners. Journal of Studies in Education, 3(1), 1-15.

Rahimi, M. \& Katal, M. (2010). Iranian Universsity students metacognitive listening strategies awareness in Learning English. Paper presented at the third national conference on Education, Tehran. 
Rahimi, M. \& Katal, M. (2011). Metacognitive Vandergrift, L \& Goh,C. C. M. (2012). Teaching strategies awareness and success in learning English as a foreign language: an and Learning Second Language Listening. overview. Procedia- Social and Behavivral Yun Wang \& Daller, J.T. (2017). Explaining Science $31 \quad$ (2012) 7381.http://dx.doi.org/10.1016/j.sbspro.2011. 12.019

Underwood, M. (1989). Teaching listening. New York: Longman.

Vandergrift, L. (1997). The strategies of second language (French) listeners: A Descriptive Study. Foreign Language Annals, 30, 387409. $\quad$ http://dx.doi.org/10.1111/j.19449720.1997.tb02362.x

Vandergrift, L. , Goh, C., Mareschal, C. \& Tafaghodatari, M.H. (2006). The Metacognitive Awareness Listening Questionnaire (MALQ): Development and validation. Language Learning, 56, 431462. listening comprehension among L2 learners of English: The contribution of general language proficiency, vocabulary knowledge and metacognitive awareness. System, 65, 139-150. https://doi.org/10.1016/ j.system.2016.12.01 $\underline{3}$

Zhao, Y. (1997). The Effects of Listeners' Control of Speech Rate on Second Language Comprehension. Applied Linguistics, 18, 49-68. https://doi.org/10.1093/applin/ $\underline{18.1 .49}$ 